logos_i_ethos_2018_2_(48), s. 7-30

DOI: http://dx.doi.org/10.15633/lie.2783

Michał Chaberek

https://orcid.org/0000-0001-8071-537X

Polska Prowincja Dominikanów

\title{
Wkład chrześcijaństwa w formowanie idei wolności w kulturze europejskiej na tle wybranych poglądów starożytnych i nowożytnych
}

W debacie dotyczącej zagadnienia wolności często spotykanym zjawiskiem jest wysuwanie zarzutu względem Kościoła, czy w ogóle religii, że tłumi wolność indywidualną jednostki poprzez narzucanie ograniczeń moralnych i wymaganie określonych praktyk religijnych. Nie wchodząc zbytnio w uproszczony charakter tego typu zarzutów, zamierzam ukazać istotny wkład religii chrześcijańskiej w odkrycie prawdziwego sensu ludzkiej wolności, które dokonało się na przestrzeni kilkuset lat oddziaływania Kościoła na kulturę europejską. Pytanie badawcze, które będzie wyznaczać drogę tych poszukiwań, można sformułować następująco: Czy chrześcijaństwo, rozumiane jako religia oparta na objawieniu Jezusa Chrystusa i głoszona przez Kościół na przestrzeni wieków, przyczyniło się do lepszego zrozumienia wolności jako właściwości ludzkiej natury, czy może raczej, jak sugerują niektórzy autorzy ${ }^{1}$, było przeszkodą w tym procesie? Aby odpowiedzieć na to pytanie, dokonam trójstopniowej analizy: najpierw zastanowię się nad starożytnym rozumieniem wolności w kulturze przedchrześcijańskiej (a), następnie omówię główne elementy nowości wprowadzonej przez religię Jezusa Chrystusa (b), wskażę źródła nowożytnych koncepcji wolności, do których zazwyczaj odwołują się 
współcześni autorzy (c), aby na końcu odpowiedzieć na postawione pytanie badawcze $(\mathrm{d})$.

\section{a. Główne intuicje starożytnych na temat ludzkiej wolności}

Jednym z poglądów kształtujących starożytne rozumienie ludzkiej wolności była reinkarnacja. Przekonanie o konieczności przejścia cyklu wcieleń przyjmowano zarówno w wierzeniach dalekiego wschodu, jak i w antycznych religiach Grecji i Rzymu². Tak na przykład w orfizmie znajdujemy takie zasady jak: 1. Dusza istnieje oddzielnie od ciała. 2. Dusza może się łączyć z dowolnym ciałem. 3. Ciało jest dla duszy więzieniem. 4. Dusza będzie uwolniona, gdy odpokutuje za winy poprzez przejście kręgu wcieleń. 5. Nieszczęściu wcielenia można zapobiec przez praktyki religijne, ascezę, niejedzenie mięsa i niezabijanie zwierząt $^{3}$. Zasady te kult orficki wywodził z mitu o Dionizosie, z którego wynikało, że człowiek składa się z dwóch pierwiastków - boskiego i ziemskiego, duszy (demona) i ciała. Pierwszy to pozostałość serca Dionizosa - syna Zeusa, zaatakowanego i zjedzonego przez tytanów. Drugi to proch po spalonych przez Zeusa szczątkach tytanów, którzy tak zostali ukarani za zabicie jego syna. Religie misteryjne $\mathrm{z}$ orfizmem na czele były impulsem do ukształtowania się tego dyskursu, który później nazwano filozoficznym ${ }^{4}$. Wpływy tych pierwotnych wierzeń znajdują się u wszystkich antycznych myślicieli. Platon podzielał pogląd o koniecznej reinkarnacji i potrzebie wyzwolenia duszy z ciała. Dla tego ponadczasowego filozofa człowiekiem była właściwie sama dusza uwięziona w obciążającym ją ciele. Ciało domaga się pożywienia i pielęgnacji, rodzi żądze, osłabia i wypacza poznanie, skupia na sobie, słowem,

2 Dla uściślenia należy dodać, że reinkarnacja dotyczy pewnego cyklu wcieleń, w których może zachodzić postęp ku wyższym formom w oparciu o zasługę za dobre życie. Natomiast pisarze chrześcijańscy i ojcowie Kościoła zwalczali samą ideę wędrówki dusz nazywaną metempsychozą.

3 Por. Orfizm, w: Popularna encyklopedia powszechna, t. 12, red. J. Pieszczachowicz, Kraków 1996, s. 221.

${ }^{4}$ Zob. G. Reale, Historia filozofii starożytnej, t. 1, przeł. E. I. Zieliński, Lublin 2000, s. 50-51. 
jest odpowiedzialne za wszystko to, co odciąga duszę od poznawania piękna i prawdy. Platoński Sokrates wypowiada między innymi takie znamienne zdanie:

Tylko tę mamy wskazówkę, istotnie, że jeśli ktoś z nas pragnie kiedy poznać coś w sposób czysty, musi się od ciała wyzwolić i samą tylko duszą oglądać rzeczywistość samą. Wtedy dopiero [...] osiągniemy mądrość, dopiero jak pomrzemy [...] a za życia nie ${ }^{5}$.

Znany motyw wzmacniający „antropologię rozdarcia” pochodzi z Fajdrosa. Pojawia się tam obraz woźnicy usiłującego prowadzić powóz zaprzęgnięty $\mathrm{w}$ dwa konie - czarny i biały, z których pierwszy dąży do tego, by wóz ściągnąć na ziemię, drugi zaś by unieść ponad niebiosa. Trzy podmioty symbolizują tu trzy sfery duszy: woźnica to rozum, intelekt bądź refleksja, biały koń to ambicja, temperament, dążenie do czegoś, zaś czarny to ziemskie rządze ${ }^{6}$. W ten sposób człowiek jest areną nieustannej walki różnych sfer wewnętrznych. Wolnością według Platona jest bycie niewolnikiem najlepszej cząstki swej duszy ${ }^{7}$. Ci, którzy wyzwolili się z oków cielesnych, stają się filozofami i mają rządzić innymi. Jednak większość ludzi - ci, którzy są zmuszeni do pracy na rzecz własnego utrzymania - nie może się uwolnić od spraw świata i dlatego, jak ukazuje to znany motyw jaskini platońskiej - pozostaje im tylko oglądanie cieni i poruszanie się w sferze złudzeń ${ }^{8}$. Dochodzi tu do głosu bezwzględny elitaryzm w pojmowaniu człowieka, społeczności, państwa. Ludzie z natury nie są równi, a każda społeczność ma hierarchię, w której możemy płynnie przechodzić od „ludzi - narzędzi” (niewolników) aż po „ludzi - bogów”.

Elitaryzm jednych grup wobec drugich zostaje jeszcze pogłębiony w poglądach społecznych Arystotelesa - będącego nie tylko,

5 Platon, Fedon, przeł. W. Witwicki, Kęty 2002, 66 d-e, s. 32.

6 Por. A. Kasia, Platona ideat wolności ascetycznej, w: Antynomie wolności. Z dziejów filozofii wolności, red. M. Drużkowski, K. Sokół, Warszawa 1966, s. 11.

7 Por. A. Kasia, Platona ideał wolności ascetycznej, dz. cyt., s. 11.

8 Zob. Platon, Państwo, przeł. W. Witwicki, Kęty 1999, 514-516, s. $220 \mathrm{nn}$. 
w ślad za swoim mistrzem Platonem, zwolennikiem, ale także wybitnym teoretykiem niewolnictwa. „Niewolnik jest żyjącym narzędziem, a narzędzie nieożywionym niewolnikiem" - pisał Stagiryta w Etyce Nikomachejskiej ${ }^{9}$. Podobnie też w Polityce: „Człowiek, który z natury nie należy do siebie, lecz do drugiego, jest z natury niewolnikiem. Należy zaś do drugiego taki człowiek, który jest czyjąś własnością, mimo iż jest człowiekiem. Przedmiot własności jest zaś narzędziem działania odrębnym od właściciela" ${ }^{\prime 10}$. Niektórzy ludzie są więc niewolnikami z natury. Ponadto istnieje w ujęciu Arystotelesa ścisły związek między wolnością i własnością, tak, że wolnymi mogą być tylko ci, którzy posiadają, gdyż oni nie muszą pracować. Wszyscy zaś rzemieślnicy i żyjący z pracy rąk własnych (w tym także artyści) nie są zdolni do cnoty, na której praktykę nie znajdują czasu. Nie przysługuje im zatem prawo bycia wolnymi obywatelami, a co za tym idzie także prawo własności.

Poglądy Platona i Arystotelesa na sprawę niewolnictwa nie były czymś wyjątkowym w świecie antycznych pogan - stanowią świadectwo powszechnie wówczas panujących praktyk. W dziedzinie antropologii Arystotelesowi udało się znacznie lepiej niż Platonowi zharmonizować wewnętrzne poruszenia człowieka, nie był on jednak pewien co do sensu życia poza rzeczywistością doczesną. Celem człowieka jest szczęście i jest ono celem ostatecznym, jednak osiąga się je w tym życiu, poprzez dojście do cnoty i intelektualnej kontemplacji prawdy ${ }^{11}$. W Etyce Nikomachejskiej pisał: „Najstraszniejszą [...] rzeczą jest śmierć, gdyż jest kresem wszystkiego, a dla zmarłego nie ma już przypuszczalnie nic dobrego ani złego" ${ }^{\prime 2}$.

Jednak najważniejszym paradygmatem kulturowym kształtującym starożytne pojęcie wolności była wszechobecna wiara w przeznaczenie.

9 Arystoteles, Etyka Nikomachejska, przeł. D. Gromska, Warszawa 1956, VIII, 1161b, s. 310.

10 Arystoteles, Polityka, przeł. L. Piotrowicz, Warszawa 2001, I, 1254a, s. 30.

11 „Najwyższym dobrem człowieka jest działanie duszy zgodne z wymaganiami jej dzielności, o ile zaś istnieje więcej rodzajów tej dzielności, to zgodne z wymogami najlepszego i najwyższego jej rodzaju” (Etyka Nikomachejska, dz. cyt., I 1098b, s. 22).

12 Poglądy Arystotelesa w kwestii „życia po śmierci” nie są spójne. Zob. Etyka Nikomachejska, dz. cyt., 1100a, 1115a, s. 30, nr 96. 
Starożytni Grecy i Rzymianie żyli w przeświadczeniu, że ostatecznie to nie świat silniejszych lub słabszych bogów kształtuje ich życie, lecz właśnie ślepy los, określany przez Greków mianem $\alpha v \alpha \gamma \kappa \eta$ (ananke), a przez Rzymian - fatum $^{13}$.

Czy ty sama jedna moja córko, zamierzasz zmienić niezwalczone Fatum? Możesz wejść sama do pałacu trzech sióstr: ujrzysz tam ogromnych wymiarów tablice wyroków wykonane z brązu i z litego żelaza, które nie lękają się ani zwalenia się z nieba, ani strasznej siły piorunów, ani żadnego zniszczenia, lecz są bezpieczne na zawsze ${ }^{14}$

- tymi słowami komentował żal bogini Wenus jej ojciec, gdy ta widziała zbliżający się nieuchronnie, śmiertelny zamach na Juliusza Cezara. I dalej czytamy:

Udręczona troskami Wenus napełniała na próżno całe niebo takimi skargami i wzruszała bogów, którzy chociaż nie mogli złamać żelaznych wyroków sędziwych sióstr, dawali jednak jawne znaki przyszłego nieszczęścia ${ }^{15}$.

Wspominane trzy siostry to greckie Mojry, rzymskie Parki - trzy boginie, władczynie ludzkiego życia ${ }^{16}$. O Herkulesie czyta się w Eneidzie:

13 W poglądach starożytnych należy rozróżnić dwa podobne stanowiska - fatalizm i determinizm. Nie różnią się one w skutkach, gdyż oba odmawiają człowiekowi wolności kształtowania własnego życia. Ten pierwszy zakłada jednak, że na losy człowieka zasadniczy wpływ wywierają jakieś siły pozaświatowe, wedle drugiego $\mathrm{z}$ tych stanowisk człowiek jest całkowicie zależny od czynników światowych - przyrody, natury, kultury itd. Wiara w ślepy los miała charakter fatalistyczny, natomiast konieczność przejścia cyklu wcieleń nosi znamiona determinizmu, gdyż wynika z działania określonych sił immanentnych, którym człowiek musi się poddać. Zob. Fatalizm, w: Powszechna encyklopedia filozofii, t. 3, red. A. Maryniarczyk, Lublin 2002, s. 375n.

14 Owidiusz, Metamorfozy, t. 2, przeł. A. Kamieńska, S. Stabryła, Wrocław 2004, XV, 809-813, s. 505.

15 Owidiusz, Metamorfozy, dz. cyt., s. 504.

16 Według Teogonii Hezjoda były to trzy córki Zeusa i Temidy, siostry hor, wyobrażane jako porządki: Lachesis (z wrzecionem w ręce) rozpoczynała nić życia, Kloto (z tabliczką lub rylcem) snuła nić dalej, Atropos (ze zwojem, klepsydrą lub wagą) przecinała nić życia. 
Prześwietne grody Troję i Echalię zdruzgotał, tysiąc lat mozołów twardych

Ścierpiał pod władzą króla Eurysteja

Z wyroku wrogiej Junony ${ }^{17}$.

A o samym Eneaszu uciekającym z portu skarży się Jutrzenka Jowiszowi:

Jeśli stać się musi

Żeby ten zbrodniarz dopłynął do portu

I dotknął stopą ziemi, jeśli takie

są od Jowisza losy, taka przyszłość

Jest przeznaczona, niechże on znękany

Wojną z zuchwałym ludem i wydarty z objęć Zulusa i wygnany z kraju,

Błaga o pomoc i patrzy na straszną

Rzeź swoich druhów ${ }^{18}$.

Zatem bogowie starożytni nie tylko podlegają fatum, tracąc tym samym również władzę nad ludźmi, ale także niejednokrotnie stają się rywalami ludzi w namiętnych walkach o względy silniejszych czy wzięcie wśród kochanków. Bezosobowe siły tego świata - greckie heimarmene mogą pchać człowieka ku najgorszym zbrodniom, mogą też wprowadzać go w sytuacje bez wyjścia. Przykład takiego działania losu znajduje się w jednej ze starożytnych tragedii - Antygonie Sofoklesa, a także w Królu Edypie. W tej ostatniej tragedii losami tytułowego bohatera rządzi ślepe $\alpha v \alpha \gamma \kappa \eta$ (los, przeznaczenie), które niezawodnie i bezlitośnie doprowadziło do realizacji w jego życiu wyroczni mówiącej, że zabije własnego ojca i poślubi swoją matkę.

W miarę rozwoju kultury grecko-rzymskiej zainteresowania filozofów przenoszą się z dziedziny kosmologii w kierunku rozważań etycznych. Trzeba przyznać, że późne osiągnięcia filozofii sokratejskiej, stoików

17 Wergiliusz, Eneida przeł. Z. Kubiak, Warszawa 1998, VIII, 391-394, s. 290-291.

18 Wergiliusz, Eneida, dz. cyt., IV, 834nn, s. 165. 
i epikurejczyków miały charakter oryginalny i przełomowy na tle innych cywilizacji starożytnych. System stoicki datowany od Zenona z Kition (ok. 300 przed Chr.) charakteryzuje się rozwiniętym humanizmem opartym na pojęciu filantropii - miłości każdego człowieka bez względu na jego pochodzenie, stan majątkowy czy wykształcenie ${ }^{19}$. Diogenes Laertios przypisał Zenonowi m.in. takie zdanie: „Istnieje niewolnictwo, które pochodzi z podboju, i drugi rodzaj, który pochodzi z kupna; jednemu i drugiemu odpowiada prawo i to prawo jest złe"20. To od Terencjusza, rzymskiego komediopisarza sympatyzującego $\mathrm{z}$ ideami stoickimi pochodzi zdanie: „Homo sum et nihil humani a me alienum puto”. Z kolei Seneka, również stoik, pisał: "Jak długo przebywamy pomiędzy ludźmi, kierujmy się w naszym postępowaniu ludzkością"21. U Marka Aureliusza, ostatniego przedstawiciela tej szkoły, znajdzie się takie zdanie: „Troska o wszystkich ludzi jest zgodna z naturą człowieczą"22.

Niemniej zorientowany antropocentrycznie stoicyzm nie uwolnił się od pesymizmu egzystencjalnego, powracającego w różnych postaciach przez cały antyk. Seneka na pytanie, co to jest wolność? odpowiada: „Nie być niewolnikiem żadnej rzeczy, żadnej potrzeby, żadnych wydarzeń, przymusić swój los do równego postępowania z sobą" ${ }^{\text {"23 }}$. W stoicyzmie ponownie ujawniają się dwa paradygmaty kulturowe: przeznaczenie i konieczność wyzwolenia z ciała. Człowiek, w myśl naczelnej zasady moralnej stoików, ma się uczynić nieczułym na wszelkie poruszenia i wpływy, ma niejako uprzedzać los przez odpowiednie przygotowanie swych emocji, ma się stać nieczuły na porywy świata, doznania i sam strach przed śmiercią. To wyzwolenie dokonuje się przez ascezę. Stoicyzm zna niemal wyłącznie wolność negatywną, nie ma zaś pomy-

19 Więcej na ten temat zob. A. Kasia, Stoicka idea wolności jako zrozumianej konieczności, w: Antynomie wolności, dz. cyt., s. 48-60.

20 Por. Diogenes Laertios, Żywoty i poglądy stynnych filozofów, przeł. K. Leśniak, Warszawa 1982, VII 1, 122, s. 425.

21 Seneka, O gniewie, przeł. L. Joachimowicz, Warszawa 1965, III, 43,5, s. 424.

22 Marek Aureliusz, Rozmyślania, przeł. M. Reiter, Warszawa 1988, III, 4, s. 23.

23 Zob. Seneka, Listy moralne do Licyliusza, przeł. W. Kornatowski, Warszawa 1998, V, 51,9, s. 193. 
słu na wolność pozytywną, gdyż, jak pisał Aureliusz: „na wszystko się godzę, co jest zgodne z tobą, o wszechświecie!”24. Ponownie powraca więc poddanie światu, losowi, siłom naturalnym bądź boskim, zawsze jednak zewnętrznym wobec człowieka.

\section{b. Nowość chrześcijaństwa}

Nie negując wartości osiągnięć kultur dalekowschodnich: indyjskiej czy chińskiej, a także kultur innych kontynentów: afrykańskich czy amerykańskich, trzeba przyznać, że filozofia, rozumiana jako poznanie rzeczywistości oparte na racjonalnych poszukiwaniach, stała się domeną kultury śródziemnomorskiej. Dojrzałe poglądy, czy też - jak można powiedzieć - systemy filozoficzne Platona i Arystotelesa, nie miały swoich odpowiedników w żadnej innej cywilizacji ${ }^{25}$. Poszukiwania filozofów pogańskich stopniowo przygotowywały kulturę antyczną na przyjęcie objawienia chrześcijańskiego. Na przestrzeni kolejnych stuleci chrześcijaństwo wprowadziło nową jakość myślenia w szereg sfer życia Europejczyków. Przede wszystkim przemieniło oczywiście religię, przynosząc zupełnie nowe formy wyznania i kultu, wypływające ze zmienionego sposobu pojmowania więzi z Bogiem (religio). Ta relacja Bóg-człowiek po raz pierwszy zaczęła być rozumiana jako miłość i forma przyjaźni. Po raz pierwszy człowiek nie był tylko przedmiotem w ręku Boga, ale kimś obdarzonym podmiotową godnością. Sam Bóg przez wcielenie i zejście do ludzi w osobie Jezusa dał dowód na to, że nie tylko człowiek szuka Boga, ale także Bóg poszukuje człowieka, że zależy Mu na jego szczęściu. Bóg w Chrystusie stał się jednym z ludzi, przez co stał się w tym sensie Bogiem widzialnym, prawdziwym Emanuelem - Bogiem z nami. To właśnie wcielenie Syna Bożego sprawiło, że przyjaźń z Bogiem odtąd stała się możliwa. Można by oczywiście rozważać ową nowość chrześcijaństwa jako religii w wielu wymiarach,

24 Aureliusz, Rozmyślania, dz. cyt., IV, 23, s. 36.

${ }^{25}$ O warunkach sprzyjających powstaniu myślenia filozoficznego w środowisku helleńskim zobacz: G. Reale, Historia filozofii starożytnej, dz. cyt., s. 44-52. 
takich jak chociażby teologia (trynitologia), dalej antropologia, formy kultu, rozumienie początku i końca świata, wyzwolenie z grzechu i ostateczne zbawienie człowieka, a nawet kosmologia i pochodzenie rodzaju ludzkiego. We wszystkich tych dziedzinach chrześcijaństwo wywarło znamię całkowicie nowej jakości w kulturze śródziemnomorskiej i zachodniej. Tutaj interesuje nas tylko jeden aspekt tej nowości - ten, który odnosi się do pojmowania ludzkiej wolności. Należy wyróżnić cztery kluczowe elementy składające się na chrześcijańską „rewolucję wolności":

\section{1) Odrzucenie fatum}

Pismo Święte w kilku miejscach mówi o przeznaczeniu człowieka, jednak ani razu nie występuje $\mathrm{w}$ nim greckie heimarmene. W Liście do Galatów Paweł mówi o sobie: „Gdy jednak spodobało się Temu, który wybrał mnie (aforisas) jeszcze w łonie matki mojej i powołał łaską swoją, [...] natychmiast, [...] skierowałem się do Arabii, a później znowu wróciłem do Damaszku" $(1,15-17)$. To samo słowo $\alpha \varphi o \rho i \zeta \omega$ występuje w kontekście powołania Barnaby i Pawła w Dziejach Apostolskich, kiedy to Duch Święty podczas modlitwy przemawia do zgromadzonego Kościoła: „Wyznaczcie mi (aforisate de moi) już Barnabę i Szawła do dzieła, do którego ich powołałem" $(13,2)$. Zauważmy, że w obu przypadkach Boży wybór zakłada ludzką współpracę, ludzką odpowiedź wyrażoną w konkretnym działaniu.

Drugim słowem określającym wybór i przeznaczenie jest słowo tithemi. Najbardziej znaczące użycie znajduje się w Ewangelii św. Jana, gdzie Pan Jezus mówi do uczniów: „Nie wyście Mnie wybrali, ale Ja was wybrałem i przeznaczyłem (etheka) was na to, abyście szli i owoc przynosili" (J 15, 16). W innym miejscu to samo słowo raz określa raz przeznaczenie do upadku ludzi nieposłusznych słowu (1 $\mathrm{P} 2,8)$, a drugim razem przeznaczenie do życia wiecznego pogan, którzy usłyszanemu słowu Bożemu uwierzyli (Dz 13, 48). Kolejnym słowem, które znajdujemy w Nowym Testamencie, jest oridzo (ustanowić, wyznaczyć) występujące w kontekście przeznaczenia Chrystusa do tego, by sądził ludzi ( $\mathrm{Dz}$ 17, 31), 
a także wybrania Jezusa przez Boga do odkupieńczej męki za ludzi (Dz 2, 23). W Ewangelii św. Łukasza Pan Jezus wypowiada o sobie takie zdanie: „Wprawdzie Syn Człowieczy odchodzi według tego, jak jest postanowione (orismenon), lecz biada temu człowiekowi, przez którego będzie wydany" (Łk 22, 22). Ostatnim i najważniejszym z punktu widzenia tych poszukiwań jest pochodzące od oridzo słowo - prooridzo. Są dwa miejsca, w których wyraźnie mówi się o przeznaczeniu człowieka. W Liście do Rzymian św. Paweł pisze:

[Bóg] tych, których od wieków poznał, tych też przeznaczył (proorisen) na to, by się stali na wzór obrazu Jego Syna, aby On był pierworodnym między wielu braćmi. Tych zaś, których przeznaczył, tych też powołał, a których powołał - tych też usprawiedliwił, a których usprawiedliwił - tych też obdarzył chwałą $(8,29.30)$.

Drugie miejsce to List do Efezjan, gdzie jest napisane:

Z miłości przeznaczył (proorisas) nas dla siebie jako przybranych synów przez Jezusa Chrystusa, według postanowienia swej woli $(1,5)[\ldots]$ W Nim dostąpiliśmy udziału my również, z góry przeznaczeni (prooristhentes) zamiarem Tego, który dokonuje wszystkiego zgodnie z zamysłem swej woli, po to, byśmy istnieli ku chwale Jego majestatu - my, którzyśmy już przedtem nadzieję złożyli w Chrystusie $(1,11)$.

Greckie heimarmene różni się znacznie od chrześcijańskiego prooridzo. O ile to pierwsze określa bezduszne i ślepe przeznaczenie, o tyle drugie oznacza przeznaczenie wynikające $\mathrm{z}$ daru kochającego Boga ${ }^{26}$. Przeznaczenie, o którym mówi Pismo Święte, jawi się zawsze w relacji osobowej między Bogiem a człowiekiem, jest otoczone miłością i zawsze ma na celu dobro człowieka. W mitologii bezosobowy, ślepy los pcha człowieka ku nieznanej przyszłości, najczęściej ku nieszczęściu, czasem ku unicestwieniu. W Piśmie Świętym przeznacza On - Bóg, który - jako byt absolutny i wszechmogący Pan całego stworzenia - zna przeszłość

26 Por. J. Salij, Czy Bóg nas zaprogramowat? Przeznaczenie a wolność, w: J. Salij, Rozpacz pokonana, Poznań 1983, s. 102-125. 
i stoi poza i ponad czasem. Stąd wynika Jego wszechwiedza, ale ponieważ jest On osobową miłością Trzech, nie chce zatracić swojego stworzenia, lecz zwraca się ku niemu w Objawieniu dokonanym na sposób ludzki. I dlatego przeznaczeniu zawsze towarzyszy wolna odpowiedź człowieka. Jezus pokazuje konsekwencje złego postępowania, ale każdy człowiek ma realny wpływ na swój los, a przez łaskę może stać się również współpracownikiem Boga w dziele zbawienia. Zatem miejsca w Piśmie Świętym mówiące o przeznaczeniu (będącym logiczną konsekwencją niesymetrycznej relacji między Stwórcą a stworzeniem) zostają zrównoważone przez wszystkie te miejsca, w których mówi się wprost o odpowiedzialności każdego człowieka za swoje życie. Nie miałoby sensu wezwanie do nawrócenia ( $\mathrm{Mk} 1,15 ; \mathrm{Ef} 5,11 ; \mathrm{Rz} 12,2)$, gdyby wszystko było zdeterminowane. Pismo Święte opowiada także historie wielu nawróceń. Zatem zmiana własnego losu nie jest jedynie teoretyczną możliwością, lecz faktem, powtarzającym się nieustannie w dziejach biblijnych i w historii Kościoła.

Podsumowując, należy zauważyć, że chrześcijaństwo mówi o jakimś rodzaju przeznaczenia, ale jednocześnie odrzuca jego pogańskie rozumienie. Różnice można opisać w trzech punktach: a) chrześcijaństwo przyjmuje relację osobową między Bogiem a człowiekiem, b) w tej relacji człowiek zawsze pozostaje wolny, c) Bóg zawsze chce dobra człowieka i pomaga mu je osiągnąć. Zatem wolność człowieka nie jest zdeterminowana, lecz ukierunkowana.

\section{2) Odrzucenie niewolnictwa}

Objawienie chrześcijańskie nie pozostawia wątpliwości odnośnie do tego, że wszyscy ludzie z natury są równi, tzn. że są dziećmi Bożymi, wszyscy tak samo powołani do tej samej nagrody. Klasyczny tekst znajduje się w Liście do Galatów:

Nie ma już Żyda ani poganina, nie ma już niewolnika ani człowieka wolnego, nie ma już mężczyzny ani kobiety, wszyscy bowiem jesteście kimś jednym w Chrystusie Jezusie $(3,28)$. 
Podobne słowa znajdujemy w Liście do Kolosan (3, 11), Rzymian $(10,12)$. Oba teksty wskazują na właściwe rozumienie równości między ludźmi, która to równość jest równością w Chrystusie, a zatem przede wszystkim równością w oczach Bożych. Jest to równość w dostępie do łaski, równość w godności przez uczestnictwo w wielkiej rodzinie ludzkiej. Nie mają tu znaczenia ani pochodzenie etniczne czy geograficzne ani rasa czy stan życia. Równość ta nie oznacza jednak identyczności. Jest jasne, że ludzie rodzą się z różnymi zdolnościami, są kształtowani przez różne środowiska i w końcu dochodzą do różnych osiągnięć. Chrześcijaństwo jest dalekie od wszelkiej utopii. To dlatego u św. Pawła znajdą się także wypowiedzi, w odniesieniu do których może się wydawać, że sankcjonują instytucję niewolnictwa (Ef 6, 5; 1 Kor 7, 21). Nie jest to jednak potwierdzenie instytucji niewolnictwa. Apostoł po prostu stwierdza, że stan niewolników funkcjonuje w ówczesnym społeczeństwie.

Jak już było powiedziane, chrześcijaństwo jest religią przede wszystkim serca i ma na celu ostateczne zbawienie, którego oczekuje nie w tym, lecz w przyszłym życiu. Dlatego w pismach pierwszych chrześcijan nie znajdziemy żadnych wezwań do rewolucji. Listy apostolskie ukazują przemianę ładu doczesnego jako pochodną przemiany serc, a przemiana instytucji społecznych nigdy nie jest warunkiem wstępnym do przyjęcia łaski. Gdy więc Pawłowi zdarza się nawrócić również niewolników pracujących $\mathrm{w}$ domach chrześcijańskich, to mówi o przemianie relacji poddaństwa $\mathrm{w}$ relację miłości. Skoro stan niewolnictwa nie wyklucza wejścia na drogę uświęcenia, to pierwotny Kościół, nie chcąc burzyć pokoju społecznego, decyduje się na tymczasowe tolerowanie go, bez popierania. Gdy tylko jednak chrześcijanie stają się na tyle liczni, że zaczynają oddziaływać na instytucje państwowe, niewolnictwo w Europie zanika. W miarę chrystianizacji kultury staje się ona coraz bardziej „antyniewolnicza". W średniowieczu dojdzie nawet do powstania zakonów zajmujących się wykupem z niewoli muzułmańskiej. 
3) Równość kobiety i mężczyzny

Biblijny opis stworzenia przedstawia kobietę i mężczyznę jako dwa sposoby istnienia tego samego gatunku ludzkiego. Jest to pierwotna jedność wynikająca ze świadomości jednego źródła pochodzenia - od Boga. Ta pierwotna jedność $w$ wyniku grzechu pierworodnego zostaje w jakiejś mierze utracona. Po grzechu Bóg mówi do kobiety, że będzie kierowała swe pragnienia ku mężowi, ten zaś będzie nad nią panował ( $\left.\mathrm{Rdz}_{3}, 16\right)$. Świat starożytny, skutkiem grzechu, zatracił pierwotną równość kobiety i mężczyzny, co przejawiało się na przykład w wielożeństwie. Pan Jezus, ogłaszając nowość chrześcijaństwa, również w tej dziedzinie odwołuje się do początku - właśnie do opisu stworzenia. To między innymi przez przywrócenie trwałości małżeństwa monogamicznego Jezus ukazuje równość kobiety i mężczyzny. I tutaj jednak równość nie oznacza utożsamienia. Kobieta z natury obdarzona specyficznymi właściwościami ciała i psychiki jest powołana także do innej roli niż mężczyzna. W odniesieniu do kobiety i mężczyzny nie można mówić o roli lepszej czy gorszej, są one po prostu inne, gdyż bardziej odpowiadają ich naturze i powołaniu. Równość ponownie wyraża się nade wszystko w dostępie do łaski, do której Bóg wzywa tak samo mężczyzn, jak i kobiety: „nie ma już mężczyzny ani kobiety, wszyscy bowiem jesteście kimś jednym w Chrystusie Jezusie" (Ga 3, 28).

Prawda o równości kobiety i mężczyzny przenikała do świadomości ludzkiej bardzo powoli, swój dojrzały wyraz znalazła dopiero w średniowiecznym porządku christianitas. Wtedy to wykształcone kobiety na równi z mężczyznami bywały królami, stawały na czele wojsk, doradzały papieżom, prowadziły handel, zajmowały się księgarstwem, a nieraz także parały się typowo męskimi zawodami, jak na przykład kowalstwem ${ }^{27}$.

W wyniku załamania porządku średniowiecznego kobiety od XVI wieku ponownie zaczynają tracić swoje prawa. Proces narastania nierówności pogłębia się aż do początku XIX wieku. Szczególnie negatywny

27 Por. M. Zięba, Kobiety i ideologia, „Arka Noego” 5-6.02.2005, s. 29. Na temat miejsca kobiet w średniowiecznej kulturze zobacz także R. Pernoud, Kobieta w czasach katedr, przeł. I. Badowska, Warszawa 1990. 
stosunek do kobiet reprezentują nurty filozoficzne i polityczne wrogie chrześcijaństwu i Kościołowi instytucjonalnemu. Nierówne traktowanie kobiet wobec mężczyzn popiera od strony teoretycznej filozofia oświecenia, zaś w praktyce ustawodawstwo napoleońskie ${ }^{28}$. W odpowiedzi na tę dyskryminację rodzi się ruch feministyczny, który kieruje się motywami pozabiblijnymi i dąży do emancypacji kobiet w ramach nowożytnego paradygmatu kultury laickiej. Jeżeli obecnie świecki feminizm nadal sytuuje się w opozycji względem Kościoła, to dzieje się tak prawdopodobnie dlatego, że niektóre z jego postulatów zakładają inne rozumienie równości (a nieraz i samej natury) kobiety i mężczyzny niż to, które Kościół odnajduje w Bożym objawieniu. Warto jednak zauważyć, że cała dyskusja na temat równości kobiet nie ma miejsca gdzie indziej, jak tylko w świecie postchrześcijańskim, gdyż to właśnie chrześcijaństwo wprowadziło samo pojęcie równości osób i dostarczyło pojęć, którymi operuje się w tej dyskusji. Ewangeliczna wizja równości odwołująca się „,do początku” (por. Mt 19, 8) niejako umożliwiła sformułowanie samego pytania o równość kobiety i mężczyzny. Dlatego jeżeli spojrzymy na zagadnienie z pewnego dystansu historycznego, zauważymy, że to właśnie chrześcijaństwo rozpoczęło proces odzyskiwania równości kobiety i mężczyzny, utraconej wskutek grzechu pierworodnego. Równość ta, związana także z wolnością, jest pochodną odkupienia, i w miarę jak duch Ewangelii przenika świat, realizuje się ona w historii.

\section{4) Nowe rozumienie człowieka}

Jest prawdą weryfikowalną historycznie, że obraz Boga w danej kulturze rzutuje na obraz człowieka. Politeistyczne kultury starożytne nie

28 Zob. np. D. Godineau, Kobieta, w: M. Vovelle, Człowiek oświecenia, przeł. J. Mieszalska, Warszawa 2001, s. 401-432. „Wiek triumfującego rozumu nie jest zatem pozbawiony paradoksów. W społeczeństwie, w którym (przynajmniej we Francji) współobecność płci jest na porządku dziennym [...] triumfuje ideologia, która bezapelacyjnie rozdziela cechy, przestrzeń i role społeczne pomiędzy płciami. Mężczyźni epoki oświecenia wymieniają z kobietami poglądy i koncepcje, lecz wątpią w ich możliwości intelektualne. I podczas, gdy oświecenie wypowiada wojnę przesądom, wrogom rozumu, filozofowie ani myślą uwolnić się od nich jeśli chodzi o kobiety [...]” (s. 406-407). 
dysponują zintegrowanym pojęciem jednostki. Człowiek jest tam rozdarty na drabinie bytów, nie jest jasne, czy bardziej przynależy do świata zwierząt czy bogów ${ }^{29}$. W greckim rozumieniu człowieka jako równego bogom, gdy brakuje pojęcia Boga transcendentnego, człowiek staje się wypadkową miotających nim sił wyższych i niższych, jest funkcją, a nie podmiotem, definiuje się go przez miejsce zajmowane w społeczeństwie. Taki obraz człowieka wynika także z przekonania o reinkarnacji. Nie można bowiem mówić o integralności człowieka, jeżeli brak nośnika tego, co w człowieku indywidualne. $\mathrm{W}$ chrześcijaństwie taką rolę pełni dusza, która jest stwarzana dla każdego człowieka osobno, w taki sposób, że łączy się tylko z tym jednym i niepowtarzalnym ciałem. Platońskie postrzeganie człowieka jako duszy uwięzionej tymczasowo w ciele również podważa integralność podmiotu. Rozdarcie, o jakim czytamy u św. Pawła ( $\mathrm{Rz} 7,14-25)$, różni się zasadniczo od platońskiego, ma bowiem wyłącznie charakter moralny, a nie ontologiczny ${ }^{30}$. Ale nawet to moralne rozdarcie między dobrym a złym postępowaniem znajduje swoje rozwiązanie w Chrystusie ${ }^{31}$.

$\mathrm{W}$ świat niezdefiniowanego podmiotu ludzkiego wkracza więc wizja chrześcijańska czerpiąca naukę o człowieku z teologii - nauki o Bogu Trójcy. W nauce tej zastosowano przede wszystkim przejęte z greckiej sztuki pojęcie osoby (prosopon), które miało wyjaśnić zależność między „jednością" a „troistością" Boga chrześcijan. Prosopon w nauce o Trójcy zyskało inne znaczenie niż grecka "maska”. Osoba stała się pojęciem

29 Bruno Snell dowodził tezy, że w Iliadzie podmiot ludzki nie jest jeszcze zintegrowany. Porównując grekę klasyczną i homerycką, Snell pokazuje, że rzeczownik psyche to jedno z wielu słów oznaczających różne aspekty świadomości. Podobnie soma jest tylko jednym z wielu słów mogących oznaczać ciało, ale także zwłoki. Snell konkluduje, że człowiek u Homera nie jest jednością, jest traktowany jako zbiór różnych części, nie ma ciała czy duszy, nie jest podmiotem, lecz zespołem funkcji. Jest także wypadkową sił, nad którymi nie panuje.

${ }^{30}$ Wskazują na to na przykład słowa, w których św. Paweł utożsamia się ze swoim ciałem: "Jestem bowiem świadom, że we mnie, to jest w moim ciele, nie mieszka dobro; bo łatwo przychodzi mi chcieć tego, co dobre, ale wykonać - nie” (Rz 7, 18).

31 „Nieszczęsny ja człowiek! Któż mnie wyzwoli z ciała, co wiedzie ku tej śmierci? Dzięki niech będą Bogu przez Jezusa Chrystusa, Pana naszego!” (Rz 7, 24). Ciało nie oznacza tu elementu człowieka, lecz wszelkie pożądania, które jako poruszenia emocji odbijają się w sposób widoczny w ciele. 
metafizycznym oznaczającym principium quod, czyli ostatni nośnik wszelkiego bytu, w przeciwieństwie do principium quo, to jest natury, przez którą podmiot działa. Boecjusz zdefiniował osobę jako „individua substantia rationalis naturae" ${ }^{32}$. W tej definicji zawierają się dwa aspekty osoby. Pierwszy - że ma ona naturę racjonalną, i to jest wspólne wszystkim osobom i stanowi o przynależności do jednego gatunku. Drugi - że jest ona substancją indywidualną, to znaczy nieprzekazywalną. To zaś oznacza, że każda osoba jest podmiotem obdarzonym godnością na mocy samego faktu bycia osobą. Pojęcie osoby jest łącznikiem, przez który obraz Boga oddziałuje na rozumienie człowieka. Można to lepiej zrozumieć, gdy wyróżnimy dwa aspekty chrześcijańskiej teologii. Pierwszy zawiera się w traktacie De Deo uno, który mówi o Bogu, że jest On jeden, wszechmogący, rozumny, dobry. I z tego aspektu wynika definicja ludzkiej natury jako animal rationale. Zwierzę racjonalne, czyli doskonałe compositum duszy i ciała - duszy, która będąc racjonalna, umożliwia człowiekowi wolny wybór. Człowiek jest więc wolny na wzór swojego Stwórcy, który obdarzył go tą wolnością i - jako że Bóg jest Miłością - powołał go do określonego celu - osiągnięcia szczęścia w pełni miłości. Drugi aspekt teologii wyraża się w nauce o Trójcy, z której wynika, że Bóg nie jest monadą, że w Nim samym zachodzą relacje świadczące, że jest On wspólnotą miłości, która może też rozlewać się na zewnątrz. Stąd zaś wynika, że również człowiek nie może być pojmowany na sposób monady, że jest powołany do komunii, ale także że jest osobą, czyli że nie roztapia się we wspólnocie lub w jednym gatunku istot rozumnych, lecz jest trwałym podmiotem, który sam stanowi o sobie. Taka „nowa” wizja człowieka najlepiej odpowiada jego najgłębszej naturze i powołaniu. Wszystkie modyfikacje kultury, w tym instytucji społecznych i religijnych w chrześcijaństwie zmierzają do tego, aby lepiej wyrażać właśnie tę nową wizję człowieka opartą na pojęciu osoby. Nowe rozumienie człowieka ma oczywiście również swoje znaczenie w interesującym nas aspekcie wolności. Otóż człowiek w tej wizji jest autorem

32 Boecjusz, Przeciw Eutychesowi i Nestoriuszowi: O dwóch naturach, 3, w: Traktaty teologiczne, przeł. R. Bielak, A. Kijewska, Kęty 2000. 
swoich czynów, a więc jest wolny i bierze odpowiedzialność za swoje działania. Nie podlega już bóstwom konieczności (fatum, ananke), lecz raczej konieczności własnego sumienia. Człowieka nie można pozbawić wolności - rozumianej jako właściwość duszy - bez zniszczenia podmiotu. Wolność należy do ludzkiej natury.

Cztery powyższe punkty są wyłomami w świecie sprzed Chrystusa, które chrześcijaństwo uczyniło w kulturze grecko-rzymskiej na drodze kształtowania się europejskiego pojęcia wolności. Aby dobrze ocenić późniejsze osiemnasto- i dziewiętnastowieczne zmagania o miejsce wolności w nauczaniu Kościoła, koniecznie trzeba wziąć pod uwagę ten szeroki historyczny kontekst.

\section{c. Nowożytna przebudowa pojęcia wolności}

Z pewnością nowożytność przyniosła zerwanie pewnej długiej, i na tym etapie już nieco przestarzałej, tradycji scholastycznej. Od XVII wieku główny nurt myśli europejskiej wyznaczyli autorzy, tacy jak: Kartezjusz, Hugo Grotius, Baruch Spinoza, Thomas Hobbes, John Locke, Gottfried Wilhelm Leibniz, Johann Christian Wolff, Dawid Hume, Jean Jacques Rousseau oraz Immanuel Kant. W swych różnorodnych systemach racjonalistycznych budowali koncepcje wolności zgoła odmienne od klasycznych ujęć Tomasza i Augustyna. Inny był też punkt wyjścia ich rozważań. Jeżeli dla Augustyna było nim pytanie unde malum?, to dla filozofów poreformacyjnych mających doświadczenie wojen wewnątrzpaństwowych pytaniem kluczowym było: Jak ludzie różnych wyznań i poglądów mogą żyć w jednym państwie? Stąd ich skoncentrowanie głównie na budowie nowego ustroju politycznego, w którym również wolność obywateli znalazłaby swoje określone miejsce.

Dla przykładu Hobbes rozważa hipotetyczną sytuację ludzkości istniejącej bez państwa. W takim stanie egoistyczni, ambitni i zazdrośni $\mathrm{z}$ natury ludzie, stanowią dla siebie nawzajem zagrożenie ${ }^{33}$. Jednak

33 „Oto bowiem między ludźmi, nad którymi nie ma władzy, jest nieustannie wojna każdego człowieka z jego sąsiadami; i nie ma tam dziedziczenia, [...] ani ziemi, ani bezpieczeństwa; ale pełna 
w takim właśnie stanie człowiek dysponuje największą wolnością, gdyż: "człowiek wolny to ten, któremu w tych rzeczach, jakie przy swojej sile i swoim dowcipie jest zdolny uczynić, nic nie przeszkadza, by uczynił to, co ma wolę czynić" ${ }^{34}$. Kiedy jednak przychodzi władza państwowa uosabiana przez suwerena (króla lub zgromadzenie narodowe), nadaje ona prawa i grozi karą tak, że ludzie są zmuszeni do zaprzestania szkodzenia sobie nawzajem. Stan państwa umożliwia zatem funkcjonowanie obywatela bez strachu, że napadnie na niego inny obywatel, ale jednocześnie, jak pisze Hobbes: „wolność poddanego leży tylko w tych rzeczach, które suweren pominął milczeniem, regulując działania ludzi”35. W koncepcji Hobbesa wolność jest rozważana wyłącznie jako liberum arbitrium ${ }^{36}$, wolność czysto negatywna, czyli taka, w której nic nie przeszkadza człowiekowi działać w sposób całkowicie dowolny. Wola z natury zmierza do zła, a jeżeli ma osiągnąć dobro, to tylko za sprawą zewnętrznej normy i przymusu. W tym ujęciu wola jest więc raczej naturalną wadą człowieka (domagającą się naprawienia przez wytwór kultury - prawo), a nie jego doskonałością. Mimo tak redukcjonistycznego podejścia Hobbesa do ludzkiej wolności warto jednak zauważyć, jak radykalnie uległ przemianie paradygmat wolnościowy w kulturze europejskiej po ponad piętnastu wiekach oddziaływania nań objawienia chrześcijańskiego. Wolność w rozumieniu Hobbesa jest bowiem logicznym przeciwieństwem wolności w rozumieniu starożytnych. Tam bowiem rządził determinizm, w którym człowiek nie miał nic do powiedzenia, tu zaś człowiek wolny ma możliwość absolutnego wyboru. Choć koncepcja ta odbiega od wizji chrześcijańskiej, jej powstanie było możliwe tylko za sprawą poszerzenia horyzontu pojęciowego, które dokonało się za sprawą chrześcijaństwa.

i bezwzględna wolność przynależy każdemu poszczególnemu człowiekowi” (T. Hobbes, Lewiatan, cz. 2, przeł. C. Znamierowski, Warszawa 1954, s. 190).

${ }^{34}$ T. Hobbes, Lewiatan, dz. cyt., s. 186.

35 T. Hobbes, Lewiatan, dz. cyt., s. 189.

${ }^{36}$ Tomasz z Akwinu uznawał, że władza duszy, jaką jest wola, może być rozpatrywana w dwóch ujęciach. W jednym aspekcie wola to voluntas, czyli jakieś pierwotne ukierunkowanie człowieka na dobro i poszukiwanie szczęścia. W drugim aspekcie wola to liberum arbitrium, czyli zdolność wyboru jednej opcji spośród całej gamy możliwości (chodziło przede wszystkim o wybór środków do osiągnięcia celu). Zob. S.th. I,83, a. 4. 
Mit „stanu natury” pojawia się także u Rousseau, który jednak okazuje się polemistą Hobbesa, ponieważ uważa, że to nie siła, lecz wolna „umowa społeczna” prowadzi do powstania państwa. Człowiek rodzi się wolny i jako taki sam z siebie jest dobry. Stąd u Rousseau pojawia się kolejny mit - „dobrego dzikusa”. Granicą wolności przyrodzonej jest tylko siła jednostki ${ }^{37}$. Jednak na pewnym etapie rozwoju ludzie nie są już w stanie funkcjonować osobno, dlatego zawiązują umowę, na mocy której każdy „oddaje swoją osobę i całą swoją moc pod naczelne kierownictwo woli powszechnej”. Zatem ponownie istnienie państwa jest złem koniecznym, ma charakter czysto praktyczny i prowadzi do zrzeczenia się części wolności na rzecz ogólnego ciała politycznego.

W obu przedstawionych poglądach (Hobbesa i Rousseau) pojawia się nowe zjawisko, mianowicie pozytywizm prawny, czyli pogląd, że prawo stanowione jest najwyższą normą postępowania i że można je dowolnie kształtować, w oderwaniu zarówno od prawa Bożego, jak i naturalnego. Inny osiemnastowieczny filozof pisał:

Wolność jest to prawo czynienia wszystkiego tego, na co ustawy pozwalają: gdyby zaś jeden obywatel mógł czynić to, czego one zabraniają, nie byłoby już wolności, ponieważ inni posiadaliby z natury rzeczy tę samą możnośćc ${ }^{38}$.

Zgoła inaczej pojmował genezę państwa Locke. U niego również pojawia się ów abstrakcyjny „stan natury”, ale w tym stanie rządzi nie absolutnie wolny wybór, lecz właśnie prawo natury, które jest prawem rozumu. Ludzie, jako dzieło Boga, wszyscy są równi i niezależni, i dlatego nikt nie powinien drugiemu wyrządzać krzywdy. Jeżeli jednak ktoś wyrządziłby krzywdę, wtedy każdy ma takie samo prawo go ukarać, skoro nie istnieje żadna władza zwierzchnia. Niestety takie karanie przestępców w celu zachowania ładu, sprawiedliwości i własności nie byłoby skuteczne, dlatego ludzie organizują odpowiednią siłę w postaci

37 Zob. J. J. Rousseau, Umowa społeczna przeł. A. Peretiatkowicz, Łódź 1948, ks. I, r. VIII, s. 24.

38 Monteskiusz, O duchu praw, przeł. T. Boy-Żeleński, t. 1, cz. 2, Warszawa 1957, s. 230. 
rządu zdolnego do zachowania porządku ${ }^{39}$. Siła ta kieruje się prawem, ale rozumienie prawa jest tu zgoła inne niż u Hobbesa czy Rousseau. Zdaniem Locke’a prawo ma gwarantować wolność, gdyż „Nie jest to wolnością, gdyby każdy robił to, co mu się podoba"40. Opowiada się zatem przeciwko samowoli, a jednocześnie za zabezpieczeniem możliwości realizacji podmiotowych doskonałości każdego człowieka. W ujęciu brytyjskiego filozofa odnajdujemy więc coś zarówno głęboko chrześcijańskiego, jak i mającego posmak nowożytnego indywidualizmu. Jeżeli uznamy Locke’a za ojca liberalizmu i reprezentanta klasycznej doktryny liberalnej, to trzeba przyznać, że tak rozumiany liberalizm plasuje się znacznie bliżej chrześcijańskiego rozumienia wolności, tak jak ją przedstawiali Augustyn i Tomasz z Akwinu, niż paralelne doktryny nowożytne. Liberalizm w ujęciu Locke’a nie był wrogi chrześcijaństwu.

Przytoczenie kilku powyższych wątków pokazuje, w jaki sposób myśliciele nowożytni wykorzystali chrześcijańskie odkrycie wolności do sformułowania własnych koncepcji, zazwyczaj sprzecznych lub nawet wrogich chrześcijaństwu, ale jednocześnie czerpiących z niego cały zasób pojęć i idei. W ujęciach najbardziej wpływowych filozofów nowożytnych można dostrzec kilka elementów wspólnych. Wolność była rozumiana przede wszystkim jako wartość autonomiczna i indywidualistyczna.

39 „Prawo natury, jak wszystkie inne prawa, które dotyczą człowieka na tym świecie, istniałoby na próżno, gdyby nie było nikogo, kto w stanie natury nie posiadałby władzy jego wykonywania, a tym samym ochrony niewinnych i powściągania przestępców" (J. Locke, Dwa traktaty o rządzie przeł. Z. Rau, Warszawa 1992, ks. 2, r. 2, \$7, s. 167).

40 Locke w Traktacie o rządzie pisał: „Prawo w samym zamyśle stanowi nie tyle ograniczenie, co wyznaczenie kierunku postępowania wolnej, rozumnej jednostki, zgodnie z jej właściwym interesem [...]”. I dalej: „Mimo, że mogą zostać popełnione błędy, to jednak celem prawa nie jest znoszenie i ograniczanie, lecz zachowanie i powiększanie wolności. Stąd też do wszystkich istot zdolnych do podlegania prawu odnosi się zasada: gdzie nie ma prawa, nie ma wolności. Wolność bowiem sprowadza się do niezależności od przymusu i gwałtu ze strony innych. Nie jest to możliwe tam, gdzie nie ma prawa. Nie jest więc to, jak się nam mówi, wolnością, gdyby każdy robił to, co mu się podoba. Któż bowiem mógłby być wolny, gdyby inny był w stanie go tyranizować? Być wolnym to znaczy dysponować i swobodnie, zgodnie $\mathrm{z}$ własnym sumieniem, kierować własną osobą, działaniem, majątkiem, całą swą własnością z przyzwoleniem prawa, któremu się podlega, nie być więc poddanym czyjejś arbitralnej woli, ale kierować się bez przeszkód własną wolą" ( J. Locke, Dwa traktaty o rządzie, dz. cyt., ks. 2, r. 7, \$57, s. 201). 
Zazwyczaj utożsamiana była z siłą lub zakresem możliwości działania, do jakich zdolny jest niczym nieograniczony podmiot. Brak było odniesienia do celu ostatecznego. W późniejszych koncepcjach, powstających zwłaszcza w okresie Wielkiej Rewolucji, wolność nabrała wręcz znaczenia samowoli, a nawet odwagi przeciwstawienia się Bożemu porządkowi państwa i świata. Nie może więc dziwić, że ujęcia te spotkały się ze sprzeciwem Kościoła.

\section{d. Wnioski końcowe}

W ramach podsumowania zbierzemy teraz kilka wniosków wynikających z dotychczasowych analiz. Najpierw należy zauważyć, że starożytność przedchrześcijańska nie postrzegała człowieka jako wolnego podmiotu. Człowiek był zdany na łaskę bądź niełaskę ślepego losu lub ułomnych bogów. To w taki kontekst kulturowy wkroczyło chrześcijaństwo ze swoim „odkryciem wolności”. Następnie teologowie Kościoła, kierując się objawieniem Jezusa Chrystusa, a także pewnymi osiągnięciami filozofii greckiej i rzymskiej, wypracowali najbardziej dojrzałe koncepcje ludzkiej wolności. Odkrycia te stanowiły przełom w rozwoju cywilizacji ludzkiej i zupełnie zmieniły pojmowanie godności człowieka. Człowiek zaczął być pojmowany jako osoba-podmiot zarówno w odniesieniu do innych ludzi, jak i do Boga. Co za tym idzie, wolność była rozumiana wszechstronnie: jako wartość przysługująca człowiekowi na mocy samego faktu bycia człowiekiem, a także jako dar Boży. Wolność postrzegana jako doskonałość człowieka domaga się wszak dalszego doskonalenia i ukierunkowania na ostateczny cel jakim jest, zgodnie z Objawieniem, zjednoczenie z Bogiem. W epoce nowożytnej wiodący filozofowie wypracowali wiele poglądów, w których wolność uległa absolutyzacji. Nieraz bywała utożsamiana $\mathrm{z}$ siłą i samowolą, utraciła swój charakter udoskonalający osobę. Zasadnicze rysy nowożytnych koncepcji wolności stały się prostym przeciwieństwem poglądów starożytnych. Z punktu widzenia chrześcijaństwa można więc dostrzec dwie skrajności - antyczny determinizm i nowożytny absolutyzm wolności, ponad którymi jak doskonałość cnoty plasuje się klasyka myśli 
chrześcijańskiej. Niemniej faktem jest, że to „chrześcijańskie odkrycie wolności” było warunkiem całej nowożytnej i współczesnej debaty wokół wolności jednostki w społeczeństwie, praw człowieka oraz zasad demokracji. Bez owego „rozszerzenia horyzontu”, które dokonało się przez oddziaływanie Ewangelii na kulturę, nowoczesny liberalizm nie byłby w ogóle możliwy. I nawet jeżeli koncepcje liberalne rodziły się nieraz w opozycji do nauczania Kościoła, to właśnie chrześcijaństwo dostarczyło pojęć, na których te koncepcje zostały oparte.

\section{Bibliografia}

Arystoteles, Etyka Nikomachejska, przeł. D. Gromska, Warszawa 1956.

Arystoteles, Polityka, przeł. L. Piotrowicz, Warszawa 2004.

Bartoś T., Bielawski K., Ścieżki wolności, Kraków 2007.

Boecjusz, Przeciw Eutychesowi i Nestoriuszowi: O dwóch naturach, w: Boecjusz, Traktaty teologiczne, przeł. R. Bielak, A. Kijewska, Kęty 2000, s. 66-84.

Diogenes Laertios, Żywoty i poglądy stynnych filozofów, przeł. K. Leśniak, Warszawa 1982. Godineau D., Kobieta, w: M. Vovelle, Człowiek oświecenia, przeł. J. Mieszalska, Warszawa 2001. Hobbes T., Lewiatan, cz. 2, przeł. C. Znamierowski, Warszawa 1954.

Kasia A., Platona ideał wolności ascetycznej, w: Antynomie wolności. Z dziejów filozofii wolności, red. M. Drużkowski, K. Sokół, Warszawa 1966, s. 9-34.

Locke J., Dwa traktaty o rządzie, przeł. Z. Rau, Warszawa 1992.

Marek Aureliusz, Rozmyślania, przeł. M. Reiter, Warszawa 1988.

Monteskiusz, O duchu praw, przeł. T. Boy-Żeleński, Warszawa 1957.

Owidiusz, Metamorfozy, t. 2, przeł. A. Kamieńska, S. Stabryła, Wrocław 2004.

Pernoud R., Kobieta w czasach katedr, przeł. I. Badowska, Warszawa 1990.

Platon, Fedon, przeł. W. Witwicki, Kęty 2002.

Platon, Państwo, przeł. W. Witwicki, Kęty 1999.

Powszechna encyklopedia filozofi, t. 3, red. A. Maryniarczyk, Lublin 2002.

Reale G., Historia filozofii starożytnej, t. 1, przeł. E. I. Zieliński, Lublin 2000.

Rousseau J. J., Umowa społeczna, przeł. A. Peretiatkowicz, Łódź 1948.

Salij J., Czy Bóg nas zaprogramował? Przeznaczenie a wolność, w: J. Salij, Rozpacz pokonana, Poznań 1983, s. 102-125. 
Seneka, Listy moralne do Licyliusza, przeł. W. Kornatowski, Warszawa 1998.

Seneka, O gniewie, przeł. L. Joachimowicz, Warszawa 1965.

Wergiliusz, Eneida, przeł. Z. Kubiak, Warszawa 1998.

Zięba M., Kobiety i ideologia, „Arka Noego” 5-6.02.2005.

\section{Abstrakt \\ Wkład chrześcijaństwa w formowanie idei wolności w kulturze europejskiej na tle wybranych poglądów starożytnych i nowożytnych}

Artykuł omawia rozwój pojęcia wolności w kulturze zachodniej. Istotnym motywem jest uwzględnienie pozytywnego wpływu chrześcijaństwa na rozwój idei wolności w obrębie myśli europejskiej. Chrześcijaństwo umożliwia (1) odrzucenie wszechobecnego fatum, (2) przezwyciężenie niewolnictwa, (3) przywrócenie równości kobiety i mężczyzny, (4) zbudowanie bardziej adekwatnej antropologii w oparciu o nowe rozumienie Boga i religii. Kultura europejska doszła do najpełniejszego rozumienia wolności dzięki inspiracjom płynącym z objawienia chrześcijańskiego, a sformułowanie liberalnych koncepcji wolności - nawet gdy stawały w opozycji do ujęcia chrześcijańskiego - było możliwe tylko dzięki pojęciom odkrytym za sprawą chrześcijaństwa.

\section{Słowa kluczowe}

wolność, chrześcijaństwo, fatum, przeznaczenie, starożytność, średniowiecze, nowożytność

\section{Abstract \\ A Contribution of Christianity to Formation of the Concept of Freedom in the European Culture: In the Context of Selected Ancient and Modern Views}

This article presents the development of the idea of freedom in Western Culture. The substantial motif of the whole text concerns positive influence of Christianity on the evolution of the idea of freedom within European thought. There are four general shifts 
in understanding freedom in Christianity: (1) the denial of fatal destiny, (2) the overcoming of slavery, (3) the restoration of equality between man and woman, (4) the development of adequate anthropology, based on new understanding of God and religion. European culture came to the deepest understanding of freedom thanks to the inspirations coming from the Christian revelation. The formulation of the liberal concepts - even if they opposed the Christian position - was possible thanks to Christianity.

\section{Keywords}

freedom, Christianity, fatum, destiny, Antiquity, Modernity 